\title{
Assessment of the Odour Impact Range of a Selected Agricultural Processing Plant
}

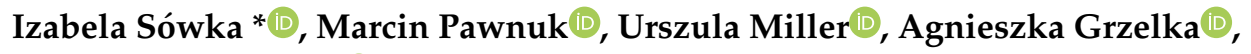 \\ Alicja Wroniszewska $@$ and Yaroslav Bezyk \\ Department of Environment Protection Engineering, Faculty of Environmental Engineering, \\ Wroclaw University of Science and Technology, Wyb. Wyspianskiego 27, 50-370 Wroclaw, Poland; \\ marcin.pawnuk@pwr.edu.pl (M.P.); urszula.miller@pwr.edu.pl (U.M.); agnieszka.grzelka@pwr.edu.pl (A.G.); \\ alicja.wroniszewska@pwr.edu.pl (A.W.); jaroslaw.bezyk@pwr.edu.pl (Y.B.) \\ * Correspondence: izabela.sowka@pwr.edu.pl; Tel.: +48-71-320-2560
}

Received: 28 July 2020; Accepted: 3 September 2020; Published: 5 September 2020

\begin{abstract}
Within the research, on the premises of an agricultural plant, the odour concentration was measured, and the odour emission was determined. The obtained values allowed us to analyse the odour distribution using the Polish reference mathematical model for four different scenarios, including (1) all identified emission sources, i.e., point and surface: scenarios 1 and 2, and (2) only point sources, scenario 3 and 4 . The values of the comparative level and the frequency of exceedances in scenarios 1 and 3 were based on the Polish draft act on counteracting odour nuisance, while the Dutch guidelines were used for scenarios 2 and 4 . Model calculations showed the potential impact of the tested structure on adjacent residential areas, i.e., in scenarios 1 and 2, the permissible value of the frequency of exceedances was exceeded at all points representing residential buildings. The exceedances for scenario 3 and 4 took place in seven out of eight and two out of eight points, respectively. The results indicated that to accurately and reliably assess the odour impact and to determine the measures to prevent and reduce odour emissions, it is necessary to consider all types of emission sources in the facilities potentially causing odour nuisance.
\end{abstract}

Keywords: dynamic olfactometry; odour concentration; emission; modelling

\section{Introduction}

In recent decades, there has been the tendency in the agri-food sector to increase both quantitative and qualitative scale of their production. In addition, the problem of excessive housing development approaching the borders of their plots is becoming increasingly important for plants of this type. Also, considering the constant increase in the society's requirements in terms of cleanliness and environment quality, all these factors contribute to the increasing number of complaints regarding excessive odour nuisance, including from the agriculture and agricultural processing sectors $[1,2]$. In 2019, the Polish Ministry of the Environment drafted the bill on the minimum distance for planned agricultural undertakings whose functioning may be associated with the risk of odour nuisance [3]; however, the proposed solutions concern only animal breeding facilities, while the problem of excessive odour nuisance also applies to other types of agricultural activities, including production of soil for mushroom farming $[4,5]$. As a result of composting processes carried out to obtain the final product, odorous chemical compounds are emitted, mainly in the form of sulphur and nitrogen compounds [4], such as: hydrogen sulphide, carbonyl sulphide, methyl mercaptan, dimethyl sulphide, carbon sulphide [6]. 
As stated in the literature [7-9], odours can be treated as air pollutants that could cause annoyance. The World Health Organization defines health as 'a state of complete physical, mental and social well-being and not merely the absence of disease or infirmity' [10]. At the same time, for many years the emission of odours from all sectors of the economy has led to people complaining about health ailments, such as headaches, dizziness or nausea. Schiffman et al. [11] quote many studies showing the importance of odour in the history of medicine. Unpleasant odours were considered to be warning signs or indicators of a potential hazard to human health. In addition, previous research has shown that the frequency of symptoms on the areas exposed to odours can increase significantly when the surrounding air is odorous [12]. For example, headaches were five times more common in people who reported experiencing frequent industrial and agricultural odours than in those who did not smell anything. Odours have also been shown to exacerbate chronic respiratory problems such as asthma [13].

As mentioned earlier, the facilities of the agri-food industry may cause odour nuisance to the local inhabitants in the vicinity of these facilities. As indicated in the literature [7,14], in order to determine the extent of the odour impact by objects that may emit unpleasant odours, it is necessary to take a number of different actions. They include, among others, the characteristics of the sources of odour emissions in the analysed object, the definition of the assessment method, the determination of sampling methods, odour concentrations and the impact range using mathematical model tools [15-18]. In order to perform mathematical modelling for assessing the odour impact range of objects that could emit odours, it is necessary to determine such reference values as the permissible level of odour concentration in the air or frequency of exceedances [19]. In Poland, in 2009, a bill on the prevention of odour nuisance was drafted [20], which was not, however, reflected in a full-fledged act. This project indicated, among others, that the value of the comparative level of the permissible concentration of odours in the air equals $1 \mathrm{ou}_{\mathrm{E}} / \mathrm{m}^{3}$ or the value of the permissible frequency of exceeding the permissible level of $1 \mathrm{ou}_{\mathrm{E}} / \mathrm{m}^{3}$ equals $3 \%$ per year. These values are often used in the literature related to the determination of the odour impact of various objects $[14,19,21,22]$. These values may differ between individual countries depending on the solutions adopted [23]. An example may be the Dutch solutions, where the comparative level of the permissible concentration of odours in the air, considered generally acceptable to humans, is up to $5 \mathrm{ou}_{\mathrm{E}} / \mathrm{m}^{3}$ and the permissible value of the frequency of exceedances of $5 \mathrm{ou}_{\mathrm{E}} / \mathrm{m}^{3}$ equals $2 \%$ per year $[19,23]$. The differences between the mentioned values, depending on the solutions used in a given country, may potentially affect the perception of the assessment of odour impact of objects such as agri-food plants, determined with the use of mathematical modelling tools. The purpose of the research was to determine the odour impact range of a selected agricultural processing facility, along with an assessment of the share of individual odour emission sources in the total odour emission. The analyses and tests carried out finally allowed to develop a strategy to reduce odour emissions from the tested object. The obtained results of mathematical modelling for various scenarios, considering two sets of guidelines based on the Polish bill and the Dutch guidelines, also allowed to check how different guidelines may affect the perception of the potential odour impact effect of the tested agri-food facility. Due to the lack of regulations in Poland related directly to odour-related issues, these types of analyses are the first in the context of the agricultural economy, covering both the partial use of raw materials and the production of a plant product for use in food production. 


\section{Materials and Methods}

\subsection{Characteristics of the Research Object}

The object of research was the plant producing mushroom growing medium. Production at the plant is carried out in three stages, and the main raw materials in the technological process are straw, chicken fertiliser, gypsum and water. Chicken fertiliser is dissolved in water with the addition of gypsum, whose task is to stabilise the $\mathrm{pH}$ of the substrate. Then the solution is added to the previously prepared straw and mixed in order to ensure adequate coverage of the straw with the solution. The soaked straw goes to the drain plate with an aerated floor. The excess draining liquid manure flows into a special tank and is used for further production. After draining off the excess liquid manure and reaching the appropriate temperature, the substrate is transported to the fermentation box with the aerated floor, where the microbiological phase begins. The loaded box is aerated at proper intervals, and the bed is transferred. The activity of microorganisms leads to an increase in temperature to $75-80{ }^{\circ} \mathrm{C}$. The duration of the entire cycle depends on the season and weather conditions. The final product is a selective, even surface in uniform colour, with optimal humidity and $\mathrm{pH}$ value. The compost prepared in this way is transported to pasteurisation and hypertrophic chambers. The goal of this phase is to obtain a unified product, free from ammonia and pathogenic fungi, and selective, i.e., ideal for the growth of mushroom mycelium and unfavourable to the growth of other fungi. The phase consists of six stages: levelling, growth for pasteurisation, pasteurisation, cooling after pasteurisation, and maturing and cooling for mycelium sowing. Mycelium is added to the cooled compost, and the whole is transported to the next chamber, where the mycelium overgrows. The prepared substrate is stored in bulk or packed. Due to the raw materials used, as well as the biological nature of the processes, the plant can be a potential source of odour emissions.

The plant in which the research was conducted is located in a small rural commune in the central part of Poland and is situated between three clusters of residential buildings (Figure 1). From the north, the site borders directly with residential areas. The distance from the nearest emitter to the most adjacent building is about $730 \mathrm{~m}$. In the north-east direction, the closest buildings are located about $800 \mathrm{~m}$ from the plant boundaries and $1100 \mathrm{~m}$ from the nearest emitter. To the south, the nearest buildings are situated at a distance of approximately $300 \mathrm{~m}$ to the plant borders and approximately $400 \mathrm{~m}$ from the nearest emitter. The remaining areas around the plant are agricultural.

\subsection{Research Methodology}

\subsubsection{Field Inspection}

The first stage of the research leading to the determination of the odour impact of the examined site was field inspection aimed at identifying the sources of the emission of unpleasant odours on the premises. During the field inspection carried out at the plant, a sensory assessment of the type and intensity of odour was carried out, and the odour concentration in the air was determined using a field olfactometer. A Nasal Ranger field olfactometer (St. Croix Sensory, Inc., Stillwater, MN, US) was used to determine odour concentrations. The measurements were carried out in accordance with the instructions provided by the manufacturer [24]. 
2.2.2. Determination of Odour Concentration and Odour Emissions from Selected Odour Emission Sources

In order to determine the odour concentrations in gases emitted from the identified odour emission sources, a measuring campaign was carried out during which air samples were taken, and odour concentrations were determined in these samples. Sampling and determination were carried out in accordance with the Polish standard PN-EN 13725: 2007: air quality-determination of odour concentration by dynamic olfactometry [25] and the German guidelines for air sampling [26].

Sampling from point sources, such as emitters located in production halls, was carried out using the CSD30 vacuum sampler (Olfasense GmbH, Germany, 2018) and the GSP dilution probe (Ecoma GmbH, Germany, 2007) for in-situ dilution. For surface sources, ventilated sampling hood (approximate dimension $1030 \mathrm{~mm}$ x $530 \mathrm{~mm}$ x $250 \mathrm{~mm}$ ) with forced air circulation (Ecoma GmbH, Germany, 2007) was used for extraction from passive sources and the probe mentioned above for in-situ dilution. The air samples were collected in PTFE plastic bags, which do not absorb or emit odours; the whole sample collection set also consisted of non-absorbent and non-emitting odours. Each bag was pre-conditioned before sampling the air. During the collection, all used equipment was regularly cleaned. The GSP dilution probe (Ecoma GmbH, Germany, 2007) was used because the intake air was too humid. Inert nitrogen was used as the dilution gas (Air Products, Poland, 2018). In the case of sampling from the leachate tank, a special float was used to keep the ventilated sampling hood from collecting from surface sources (Ecoma GmbH, Germany, 2007) on the surface of the container. In addition, in accordance with the requirements [25], such parameters as gas temperature, ambient temperature, ambient pressure, pressure in point emitters, gas humidity, ambient humidity, flow velocity in point emitters (Testo 425-2 with IAQ probe and thermo anemometer, Testo, Poland, 2013) and dimensions of individual emitters were controlled during sampling. During the entire measurement campaign comprising five measurement series carried out on 10 April 2019, 17 April 2019, 24 April 2019, 27 April 2019, and 29 April 2019, a total of 55 air samples were taken.

Determination of odour concentrations in the samples taken was carried out with dynamic olfactometry using the YES/NO method described in PN EN 13725: 2007: air quality-determination of odour concentration by dynamic olfactometry [25]. Immediately after the completion of sampling on a given day, these samples were transported to the Accredited Laboratory of Olfactometric Testing. Transport and storage of samples before determination was in accordance with the guidelines contained in the standard [25]. Odour concentration determinations were carried out using a TO8 4 bench olfactometer (Ecoma GmbH, Germany, 2007). The measuring team consisted of four assessors and one operator. Each team member had been appropriately trained on the reference substance, which is n-butanol in accordance with the provisions of the standard [25]. The determined odour concentrations were presented in European odour units per cubic meter $\left(\mathrm{ou}_{\mathrm{E}} / \mathrm{m}^{3}\right)$.

Emission of odours from selected sources in which odour concentrations were determined was calculated, taking into account the type of source $[27,28]$. Emissions from point sources were calculated according to Equation (1):

$$
\mathrm{OER}_{\text {PointSsource }}=\mathrm{C} \times \mathrm{V}
$$

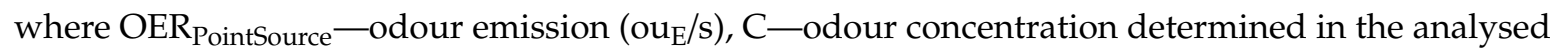
sample by dynamic olfactometry $\left(\mathrm{ou}_{\mathrm{E}} / \mathrm{m}^{3}\right)$, V-the gas flow in the emitter $\left(\mathrm{m}^{3} / \mathrm{s}\right)$.

For surface sources, the obtained concentrations were used to calculate the specific emission rate (SOER) according to Equation (2):

$$
\mathrm{SOER}=(\mathrm{C} \times \mathrm{Vs}) / \mathrm{A}_{\mathrm{S}}
$$

where SOER - unit emission of odours $\left(\mathrm{ou}_{\mathrm{E}} / \mathrm{m}^{2} / \mathrm{s}\right), \mathrm{C}$-odour concentration determined in the analysed sample by dynamic olfactometry $\left(\mathrm{ou}_{\mathrm{E}} / \mathrm{m}^{3}\right), \mathrm{V}$ - the stream of gas flow under the cover for the sampling of odours from static surface sources equal $0.075 \mathrm{~m}^{3} / \mathrm{s}, \mathrm{A}_{\mathrm{s}}$ - cover area for taking odour samples equal $0.5 \mathrm{~m}^{2}$. 
Then, to calculate odour emissions from a given surface source, Equation (3) was used:

$$
\mathrm{OER}_{\text {AreaSource }}=\mathrm{SOER} \times \mathrm{A}
$$

where OER $_{\text {AreaSource }}$-odour emission from a surface source $\left(\mathrm{ou}_{\mathrm{E}} / \mathrm{s}\right), \mathrm{SOER}$ - unitary odour emission $\left(\mathrm{ou}_{\mathrm{E}} / \mathrm{m}^{2} / \mathrm{s}\right)$, A-surface area of the tested source $\left(\mathrm{m}^{2}\right)$.

These data were used to assess the odour impact of the tested object by modelling the spread of contaminants.

\subsubsection{Modelling of the Spread of Odour Pollutants}

The assessment of the odour impact of plants that can emit odorous substances is a comprehensive task. Therefore, the characteristics of the sources of odour emissions alone is not sufficient. Thus, one of the common practices is to use mathematical models to determine this impact [14]. The models used may differ from each other both in mathematical approach, degree of complexity and application possibilities [7,14]. In Poland, guidelines for modelling the spread of pollutants in the air are included in the Regulation of the Minister of the Environment of 26 January 2010, on reference values for specific substances in the air (Journal of Laws of 2010, No. 16, item 87) [29]. The mathematical foundations described in the Regulation mentioned above define the so-called reference model: the Gaussian plume model based on the Pasquill formula. The formula of the model is as follows [21,29]:

$$
S_{x y z}=\frac{E_{g}}{2 \pi \bar{u} \sigma_{y} \sigma_{z}} * \exp \left(-\frac{y^{2}}{2 \sigma_{y}^{2}}\right) *\left\{\exp \left[-\frac{(z-H)^{2}}{2 \sigma_{z}^{2}}\right]+\exp \left[-\frac{(z+H)^{2}}{2 \sigma_{z}^{2}}\right]\right\} * 1000
$$

where $S_{x y z}$-the concentration of the substance in the air averaged for one hour $\left(\mu \mathrm{g} / \mathrm{m}^{3}\right)$;

$E_{g}$-maximum emission of gaseous substance $(\mathrm{mg} / \mathrm{s})$;

$\sigma_{y}$-horizontal atmospheric diffusion coefficient (m);

$\sigma_{z}$-vertical atmospheric diffusion coefficient $(\mathrm{m})$;

$\bar{u}$-average wind velocity in the layer from the geometric height of the emitter $h$ to the effective height of the emitter $H(\mathrm{~m} / \mathrm{s})$;

$y$-component of the distance of the emitter from the point for which calculations are made perpendicular to the wind direction $(\mathrm{m})$;

$z$-the height at which the concentration of the substance in the air is calculated (m).

The model mentioned above was used, among others, for the assessment of the odour impact of a waste management plant [14], the assessment of the odour impact of a waste composting plant located at the waste management plant [21], the odour assessment of an industrial facility [22], and the odour impact assessment of a sewage treatment plant [19]. Therefore, it was used to assess the olfactory impact of the farm site under study. For modelling, Operat Fb software (PROEKO R.S., Poland) [30] was used in accordance with the guidelines contained in the regulation mentioned above [29]. This model enables simulation of the spread of odour pollutants and presentation of its results in the form of average annual concentrations, maximum hourly concentrations and the frequency of exceedances.

Emission data obtained during sampling were used as input for modelling, including parameters such as speed, gas temperature, dimensions and heights of emitters and the time of emission of odour-forming gases (emitter working time in a year) (see Table 1). 
Table 1. Parameters of tested emitters.

\begin{tabular}{|c|c|c|c|c|c|c|c|}
\hline Odour Source & Symbol & Height (m) & $\begin{array}{l}\text { Dimensions } \\
(\mathrm{m} \times \mathrm{m})\end{array}$ & Amount (pcs.) & $\begin{array}{c}\text { Gas Velocity } \\
(\mathrm{m} / \mathrm{s})\end{array}$ & $\begin{array}{c}\text { Gas Temperature } \\
\left({ }^{\circ} \mathrm{C}\right)\end{array}$ & $\begin{array}{l}\text { Working Time Pe } \\
\text { Year (in Reference } \\
\text { to } 8760 \mathrm{~h} \text { ) }\end{array}$ \\
\hline Drain plate & Surface emitter 1 & 4.5 & $23.0 \times 45.0$ & 1 & $-* *$ & $19.4^{* * *}$ & 8760 \\
\hline Storage boxes without a roof & Surface emitter 2 & 3.0 & $9.0 \times 22.0$ & 8 & $-* *$ & $29.0^{* * *}$ & 8760 \\
\hline Covered storage boxes & Surface emitter 3 & 3.0 & $11.0 \times 21.0$ & 7 & $-* *$ & $26.6^{* * *}$ & 8760 \\
\hline Covered storage boxes & Surface emitter 4 & 4.5 & $8.0 \times 45.0$ & 7 & $-* *$ & $33.6^{* * *}$ & 8760 \\
\hline Storage boxes for droppings & Surface emitter 5 & 3.0 & $14.0 \times 25.0$ & 1 & $-* *$ & $30.3^{* * *}$ & 8760 \\
\hline Leachate tank & Surface emitter 6 & 2.0 & diameter $10.0 \mathrm{~m}$ & $2 *$ & $-* *$ & $19.4^{* * *}$ & 2920 \\
\hline Hall A/Phase II—ripening & Point emitter 1 & 11 & $1.0 \times 1.4$ & 6 & 3.16 & 47.1 & 6254 \\
\hline Hall A/Phase II-pasteurisation & Point emitter 2 & 11 & $1.0 \times 1.4$ & 7 & 1.95 & 44.8 & 6254 \\
\hline Hall A/Phase II—alignment & Point emitter 3 & 11 & $1.0 \times 1.4$ & 6 & 2.13 & 43.1 & 6254 \\
\hline Hall A/Phase III—overgrowth & Point emitter 4 & 11 & $1.0 \times 1.4$ & 6 & 2.75 & 25.4 & 6254 \\
\hline Hall B/Phase II—ripening & Point emitter 5 & 11 & $1.0 \times 1.4$ & 6 & 2.35 & 44.7 & 6254 \\
\hline Hall B/Phase II-pasteurisation & Point emitter 6 & 11 & $1.0 \times 1.4$ & 6 & 2.22 & 52.4 & 6254 \\
\hline Hall B/Phase II—alignment & Point emitter 7 & 11 & $1.0 \times 1.4$ & 6 & 1.66 & 45.1 & 6254 \\
\hline Hall B/Phase III—overgrowth & Point emitter 8 & 11 & $1.0 \times 1.4$ & 6 & 2.24 & 23.3 & 6254 \\
\hline
\end{tabular}

* Due to the specificity of the emitter (only one tank aerated), only one tank for leachate was included in the modelling. ${ }^{* *}$ Gas velocity not measured due to measurement specificity (passive surface source, measurement methodology described in Section 2.2.2). ${ }^{* * *}$ Due to model limitations, the surface gas temperature was not included in the modelling. 
Calculations of the aerodynamic roughness coefficient of the terrain were made in accordance with the methodology in the regulation [29]. Its value was 0.083 .

A wind rose was selected for model analyses (Figure 1) for the nearest measuring station about $35 \mathrm{~km}$ away from the plant site. The source of the meteorological data was Operat $\mathrm{Fb}$ software [30].

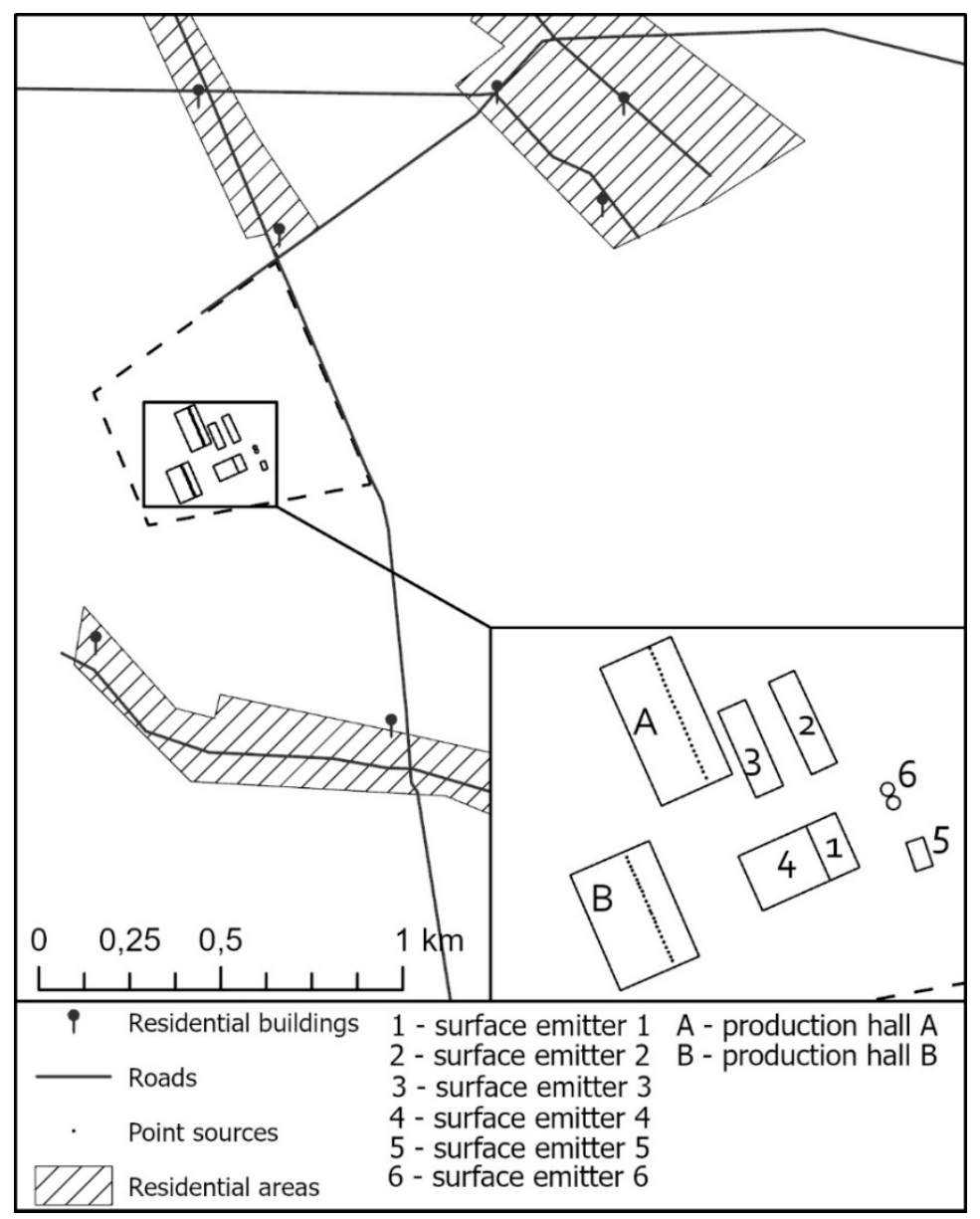

Figure 1. Location of odour emission sources on the premises of the examined plant together with marked residential zones (map based on a topographic map available in ArcGIS Pro software).

Calculations were made for a measuring grid of $2800 \mathrm{~m}$ (X-axis) x $2600 \mathrm{~m}$ ( $($-axis). The measuring grid increment is $100 \mathrm{~m}$.

In the analysis of the odour effect of the examined object, four calculation scenarios were assumed (Table 2) using the modelling of odour contamination spreading to assess the odour effect of the examined object. The expected scenarios differ in the adopted comparative levels of the permissible concentration of odour in the air, the permissible frequency of exceeding the comparative level, and the type of emitters included in the modelling. The draft for Polish Act on counteracting odour nuisance of 27 February 2009 [19,20] (for scenarios 1 and 3) and the Dutch guidelines [19] (for scenarios 2 and 4) were used to establish comparative levels and the frequency of exceedances. In scenarios 1 and 2 , all sources identified in the examined site, both point and surface, were included, while in scenarios 3 and 4, only point sources were included (for the characteristics of the sources see Tables 1 and 3). 
Table 2. Characteristics of calculation scenarios used in the assessment of the odour impact of the tested object using model tools.

\begin{tabular}{|c|c|c|c|c|}
\hline Scenario No. & $\begin{array}{c}\text { Comparative } \\
\text { Level of } \\
\text { Permissible } \\
\text { Concentration of } \\
\text { Odours in the Air } \\
\left(\mathrm{ou}_{\mathrm{E}} / \mathrm{m}^{3}\right)\end{array}$ & $\begin{array}{c}\text { Permissible } \\
\text { Frequency of } \\
\text { Exceeding the } \\
\text { Reference Level } \\
(\%)\end{array}$ & Based on Guidelines & Emitters Included \\
\hline 1 & 1.0 & 3.0 & $\begin{array}{l}\text { draft bill for the Polish } \\
\text { Act on counteracting } \\
\text { odour nuisance }[16,17]\end{array}$ & $\begin{array}{l}\text { point emitters and } \\
\text { surface emitters } \\
\text { (Tables } 1 \text { and } 3 \text { ) }\end{array}$ \\
\hline 2 & 5.0 & 2.0 & Dutch guidelines [16] & $\begin{array}{l}\text { point emitters and } \\
\text { surface emitters } \\
\text { (Tables } 1 \text { and } 3 \text { ) }\end{array}$ \\
\hline 3 & 1.0 & 3.0 & $\begin{array}{l}\text { draft bill for the Polish } \\
\text { Act on counteracting } \\
\text { odour nuisance }[16,17]\end{array}$ & $\begin{array}{l}\text { point emitters } \\
\text { (Tables } 1 \text { and } 3 \text { ) }\end{array}$ \\
\hline 4 & 5.0 & 2.0 & Dutch guidelines [16] & $\begin{array}{l}\text { Point emitters } \\
\text { (Tables } 1 \text { and } 3 \text { ) }\end{array}$ \\
\hline
\end{tabular}

Table 3. Results of odour concentration measurements along with the measured parameters necessary to carry out modelling together with the calculated odour emission from selected sources at the area of the examined object.

\begin{tabular}{ccccc}
\hline Odour Source & $\begin{array}{c}\text { Average Odour } \\
\text { Concentration } \\
\left(\mathbf{o u}_{\mathrm{E}} / \mathbf{m}^{\mathbf{3}}\right)^{*}\end{array}$ & $\begin{array}{c}\text { Odour Emission } \\
\text { Form a Single } \\
\text { Emitter }\left(\mathbf{o u}_{\mathrm{E}} / \mathbf{h}\right)\end{array}$ & $\begin{array}{c}\text { Total Odour } \\
\text { Emission } \\
\left(\mathbf{o u}_{\mathrm{E}} / \mathbf{h}\right)\end{array}$ & $\begin{array}{c}\text { Percentage Share } \\
\text { in Total Emissions } \\
\mathbf{( \% )}\end{array}$ \\
\hline Surface emitter 1 & 3919 & 2190.33 & 2190.33 & 8.00 \\
Surface emitter 2 & 8865 & 947.85 & 7582.77 & 27.71 \\
Surface emitter 3 & 4910 & 612.47 & 4287.31 & 15.67 \\
Surface emitter 4 & 3623 & 704.31 & 4930.18 & 18.02 \\
Surface emitter 5 & 7268 & 1466.83 & 1466.83 & 5.36 \\
Surface emitter 6 & 123,613 & 5239.96 & 5239.96 & 19.15 \\
Point emitter 1 & 894 & 14.24 & 85.43 & 0.31 \\
Point emitter 2 & 5899 & 57.98 & 405.83 & 1.48 \\
Point emitter 3 & 1230 & 13.20 & 79.23 & 0.29 \\
Point emitter 4 & 454 & 6.29 & 37.75 & 0.14 \\
Point emitter 5 & 1000 & 11.84 & 71.06 & 0.26 \\
Point emitter 6 & 13,523 & 151.31 & 907.84 & 3.32 \\
Point emitter 7 & 571 & 4.78 & 28.66 & 0.10 \\
Point emitter 8 & 763 & 8.61 & 51.68 & 0.19 \\
& $\mathrm{SUM}$ & & $27,364.86$ & 100 \\
\hline
\end{tabular}

* The average value of the odour concentration calculated on the basis of three samples taken-in compliance with the conditions of PN EN 13725: 2007 [25].

\section{Research Results and Discussion}

\subsection{Odour Concentration Results}

Based on field inspection, eight main facilities are located in the plant, which is the source of odour emissions: two production halls with organised emissions (point emitters located on the roofs: point emitters 1-8) and surface sources such as drain plate (surface emitter 1), two tanks with agitators (surface emitter 6), two boxes for chicken manure (surface emitter 5), and three types of storage boxes (surface emitters 2, 3, and 4). In the case of production halls (Hall A and Hall B), four types of emitters associated with a different phase of the production process are located in each hall.

Figure 1 shows the location of sources in the investigated plant area. However, the results in terms of odour concentration and odour emission calculations for the analysed sources are summarised in Table 3. 
Odour concentrations obtained during olfactometric analyses indicate that surface sources are, in most cases, characterised by higher average odour concentrations than in the case of organised (point) sources. The exceptions are point emitter 2 (odour concentration equal $5899 \mathrm{ou}_{\mathrm{E}} / \mathrm{m}^{3}$ ) and point emitter 6 (odour concentration equal 13,523 $\mathrm{ou}_{\mathrm{E}} / \mathrm{m}^{3}$ ), which were associated with the pasteurisation process. Therefore, it can be concluded that in the case of organised emissions at the analysed plant, the pasteurisation process is the most odorogenic process. The highest odour concentration was recorded in the case of surface emitter 6, which was the leachate tank: odour concentration equal $123,613 \mathrm{ou}_{\mathrm{E}} / \mathrm{m}^{3}$.

In the case of calculated odour emission, point emitters 2 and 6 were characterised by the highest odour emission, both in terms of conversion into one emitter (point emitter $2-57.98 \mathrm{ou}_{\mathrm{E}} / \mathrm{h}$, point emitter $6-151.31 \mathrm{ou}_{\mathrm{E}} / \mathrm{h}$ ), as well as in the case of conversion into emission sum of emitters (spot emitter $2-405.83 \mathrm{ou}_{\mathrm{E}} / \mathrm{h}$, spot emitter $6-907.84 \mathrm{ou}_{\mathrm{E}} / \mathrm{h}$ ). In the case of surface emitters, when considering the value of emissions from one emitter, the leachate tank with emission level $5239.96 \mathrm{ou}_{\mathrm{E}} / \mathrm{h}$ (surface emitter 6) was also the dominant one, while when converting the emission to the number of emitters, surface emitter 2 is the most dominant one-the total emission from this emitter is $7582.77 \mathrm{ou}_{\mathrm{E}} / \mathrm{h}$.

Emission data (Table 3) together with technological parameters (Table 1) and guidelines for individual calculation scenarios (Table 2) were used to model the spread of odour pollutants from a selected plant using Operat $\mathrm{Fb}$ software [30].

\subsection{Modelling Results for Odour Spread}

The figures show the results of mathematical modelling using Operat $\mathrm{Fb}$ software. The results show the distribution of maximum one-hour concentrations (Figure 2), the frequency distribution of exceedances (Figure 3, Figure 5) and the distribution of average annual concentrations (Figure 4 for scenario 1 and scenario 2).

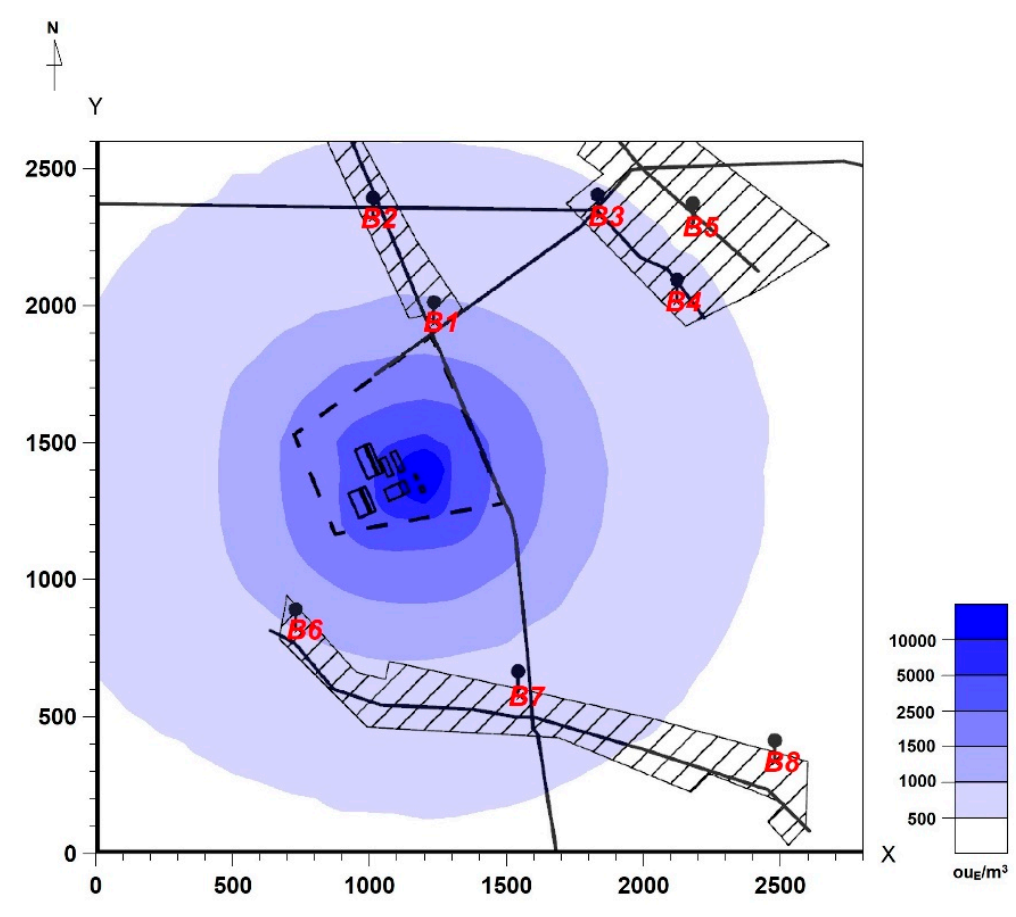

Figure 2. Maximum one-hour concentrations $\left(\mathrm{ou}_{\mathrm{E}} / \mathrm{m}^{3}\right)$ for scenario 1 . 


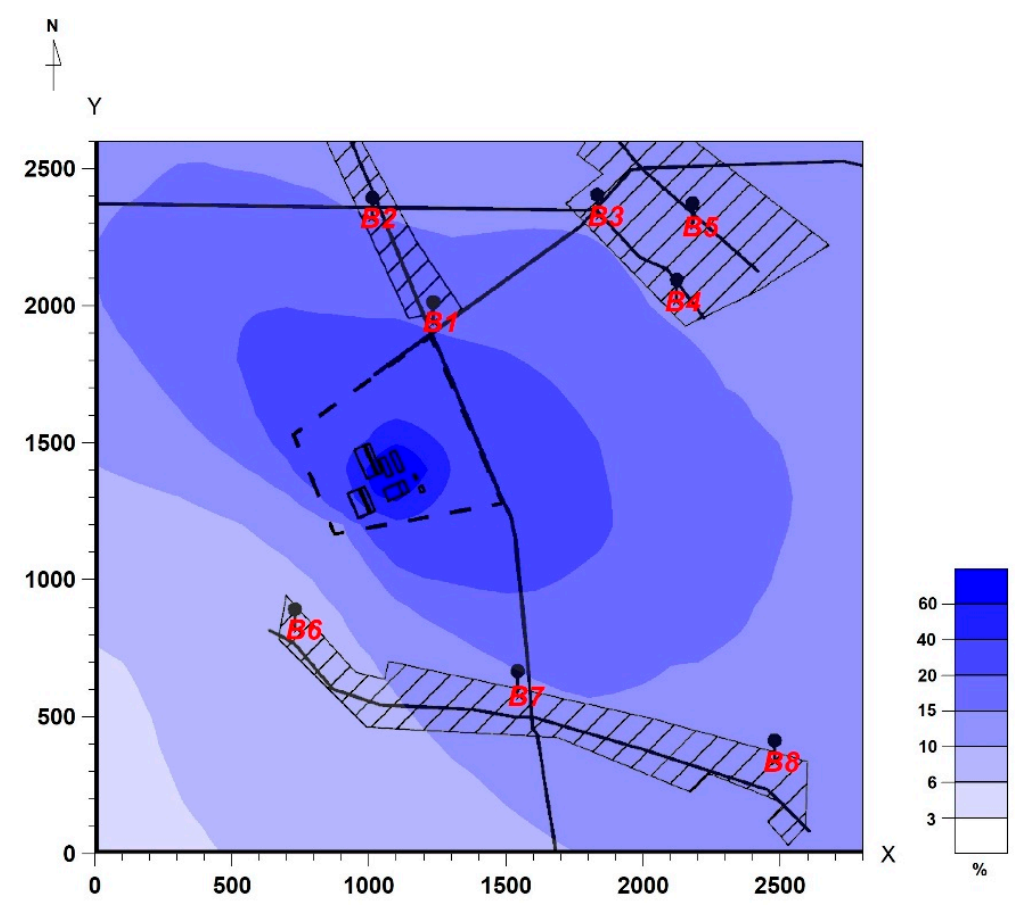

Figure 3. Frequency of exceedances $1 \mathrm{ou}_{\mathrm{E}} / \mathrm{m}^{3}$ for scenario 1 (permissible frequency of exceedances of $3 \%$ during the year).

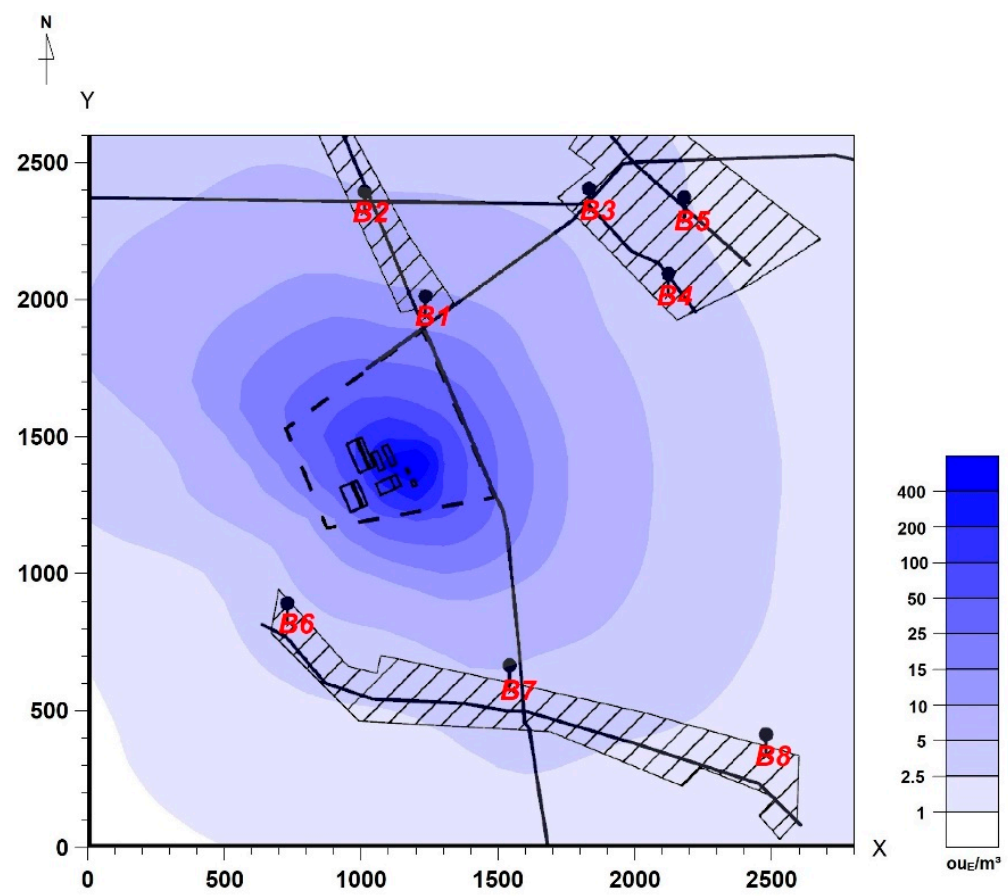

Figure 4. Average annual concentrations $\left(\mathrm{ou}_{\mathrm{E}} / \mathrm{m}^{3}\right)$ for scenario 1.

The results of analyses and calculations show that the maximum value of one-hour concentrations for scenario 1 based on the Polish draft law [20] was 23,006 ou $/ \mathrm{m}^{3}(X=1200, Y=1400)$ in the immediate vicinity of the surface emitter 6 (leachate tank). The maximum frequency of exceedances obtained for scenario 1 was $100 \%(X=1,100, Y=1,400)$. This value was read between emitters No. 1 (drain plate-surface monitor 1) and No. 2 and 3 (storage boxes-surface emitter 2 and 3). The maximum average annual concentration was recorded at the same point as the maximum one-hour 
concentration $(X=1200, Y=1400)$ and was $695 \mathrm{ou}_{\mathrm{E}} / \mathrm{m}^{3}$. All these values were obtained within the limits of the tested plant near the surface emitters.

Figure 5 presents the frequency distribution of exceedances obtained for scenario 2 . The maximum value was obtained, as in the case of scenario 1 at the receptor point, $X=1,100, Y=1,400$ and amounted to $100 \%$. For scenario 2, no distributions of maximum one-hour concentrations and average annual concentrations were presented as they are identical to the values obtained for scenario 1.

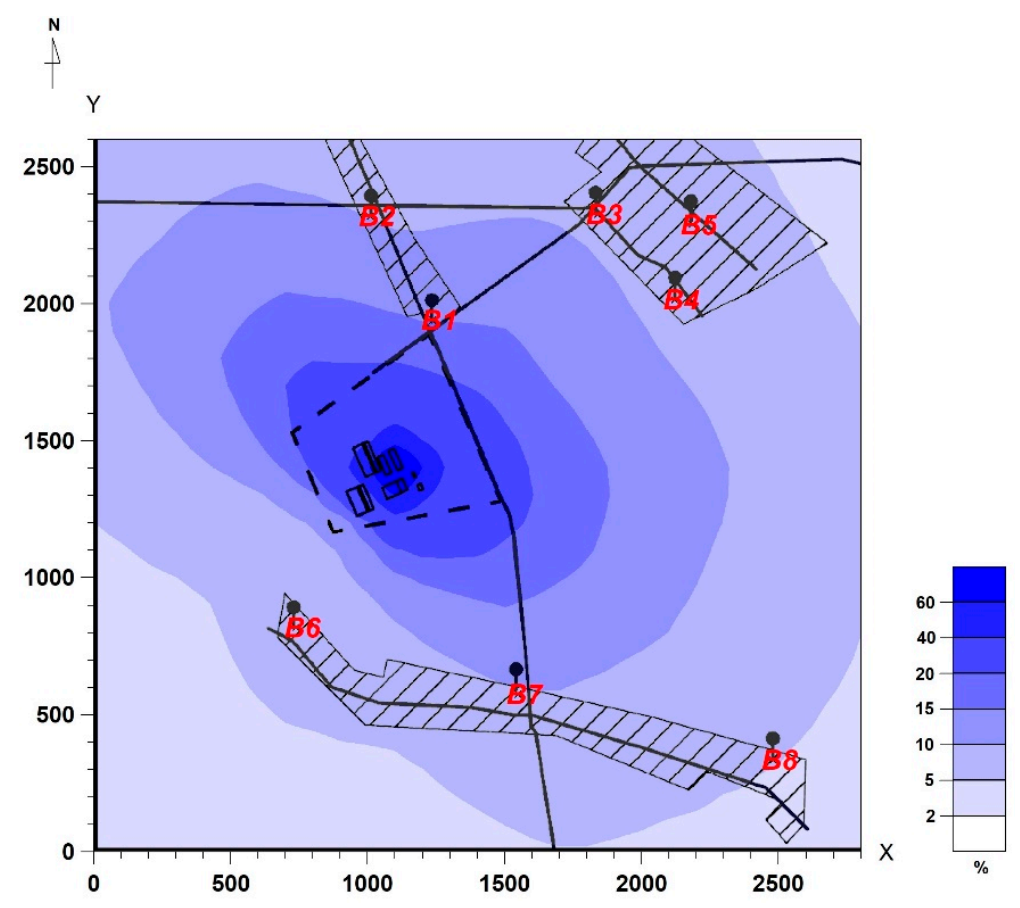

Figure 5. Frequency of exceedances $5 \mathrm{ou}_{\mathrm{E}} / \mathrm{m}^{3}$ for scenario 2 (permissible frequency of exceedances equal to $2 \%$ per year).

The performed analyses also included the points representing residential buildings (B1-B8 in Figures 2-5) as an additional grid, which allowed to obtain the maximum hourly concentrations, the average annual concentrations, and the frequency of exceedances at the building level in scenarios 1 and 2. In Table 4, modelling results for additional grid have been compared.

Table 4. Modelling results for scenarios 1 and 2 for an additional grid representing residential buildings.

\begin{tabular}{|c|c|c|c|c|c|c|}
\hline \multirow[b]{2}{*}{ Point Symbol } & \multicolumn{3}{|c|}{ Scenario 1} & \multicolumn{3}{|c|}{ Scenario 2} \\
\hline & $\begin{array}{c}\text { Maximum } \\
\text { One-Hour } \\
\text { Concentrations } \\
\left(\mathrm{ou}_{\mathrm{E}} / \mathrm{m}^{3}\right)\end{array}$ & $\begin{array}{l}\text { Average Annual } \\
\text { Concentrations } \\
\quad\left(\operatorname{ou}_{\mathrm{E}} / \mathrm{m}^{3}\right)\end{array}$ & $\begin{array}{c}\text { Frequency of } \\
\text { Exceedances } \\
(\%)\end{array}$ & $\begin{array}{c}\text { Maximum } \\
\text { One-Hour } \\
\text { Concentrations } \\
\left(\mathrm{ou}_{\mathrm{E}} / \mathrm{m}^{3}\right)\end{array}$ & $\begin{array}{c}\text { Average Annual } \\
\text { Concentrations } \\
\left(\text { ou }_{\mathrm{E}} / \mathrm{m}^{3}\right)\end{array}$ & $\begin{array}{c}\text { Frequency of } \\
\text { Exceedances } \\
(\%)\end{array}$ \\
\hline B1 & 1164 & 12.7 & 19.2 & 1164 & 12.7 & 14.8 \\
\hline B2 & 668 & 5.8 & 15.1 & 668 & 5.8 & 9.9 \\
\hline B3 & 555 & 4.0 & 14.5 & 555 & 4.0 & 8.8 \\
\hline B4 & 578 & 3.3 & 14.4 & 578 & 3.3 & 8.7 \\
\hline B5 & 463 & 2.6 & 13.2 & 463 & 2.6 & 7.1 \\
\hline B6 & 989 & 3.7 & 8.8 & 989 & 3.7 & 6.7 \\
\hline B7 & 761 & 4.2 & 13.7 & 761 & 4.2 & 9.7 \\
\hline B8 & 361 & 1.9 & 12.1 & 361 & 1.9 & 5.2 \\
\hline
\end{tabular}

Analysing the obtained results (Table 4) and concentration distributions (Figures 2-5), in the case of maximum one-hour concentrations, buildings B1 and B6 are located in the most unfavourable location. The obtained hourly concentration values were $1164 \mathrm{ou}_{\mathrm{E}} / \mathrm{m}^{3}$ and $989 \mathrm{ou}_{\mathrm{E}} / \mathrm{m}^{3}$, respectively, for points B1 and B6. On the other hand, the exceedances frequency in these points amounted to $19.2 \%$ and $8.8 \%$, respectively, for scenario 1 (permissible frequency of exceedances at the level of $3 \%$ 
per annum for $1 \mathrm{ou}_{\mathrm{E}} / \mathrm{m}^{3}$ ) and $14.8 \%$ and $6.7 \%$ for the European scenario (permissible frequency of exceedances at $2 \%$ per annum for $5 \mathrm{ou}_{\mathrm{E}} / \mathrm{m}^{3}$ ). The results obtained for the frequency of exceedances for point $\mathrm{B} 1$ are also the highest values read in the additional grid. For all points representing residential buildings, we are dealing with exceeding the allowable frequency of exceedances for both scenario 1 and scenario 2 . In scenario 1, these values range from $8.8 \%$ to $19.2 \%$, and in the European scenario, from $5.2 \%$ to $14.8 \%$.

The analysis of the percentage share in the total emission (Table 3) clearly shows that in the case of odour emission, surface sources dominate in the area of the examined object, which accounts for $93.91 \%$ of the total emission. In the case of point sources, their share is smaller, and it amounts to $6.09 \%$. Surface sources as sources of the so-called fugitive emissions make it difficult to estimate emissions from these sources. Therefore, during modelling, it is not possible to accurately estimate emissions as in the case of point source emissions, which may result in an increase in the values obtained by modelling and thus an increase in the odour impact of the tested object. For comparative purposes, modelling was carried out for scenarios that include only point sources (scenarios 3 and 4). Details of these scenarios are provided in Table 2. Another reason that may cause a problem in determining the real values of emissions from surface sources is the sampling methodology. As indicated in the literature [31,32], the type of sampling method used for surface sources, especially in the case of passive liquid surface sources, such as leachate tanks, may have an impact on the determined odour concentrations in samples from such sources with the possibility to affect the results of mathematical modelling.

The figures below show the distribution of maximum one-hour odour concentrations (Figure 6), the frequency distribution of exceedances (Figure 7, Figure 9) for scenario 3 and scenario 4 , and the distribution of average annual concentrations for scenario 3 (Figure 8). Similar to scenarios 1 and 2. For scenario 4 no maximum hourly and average annual concentration distributions are presented as they are identical to the values obtained for scenario 3. Also included are additional grids for housing repairs (B1-B8 in Figures 6-9).

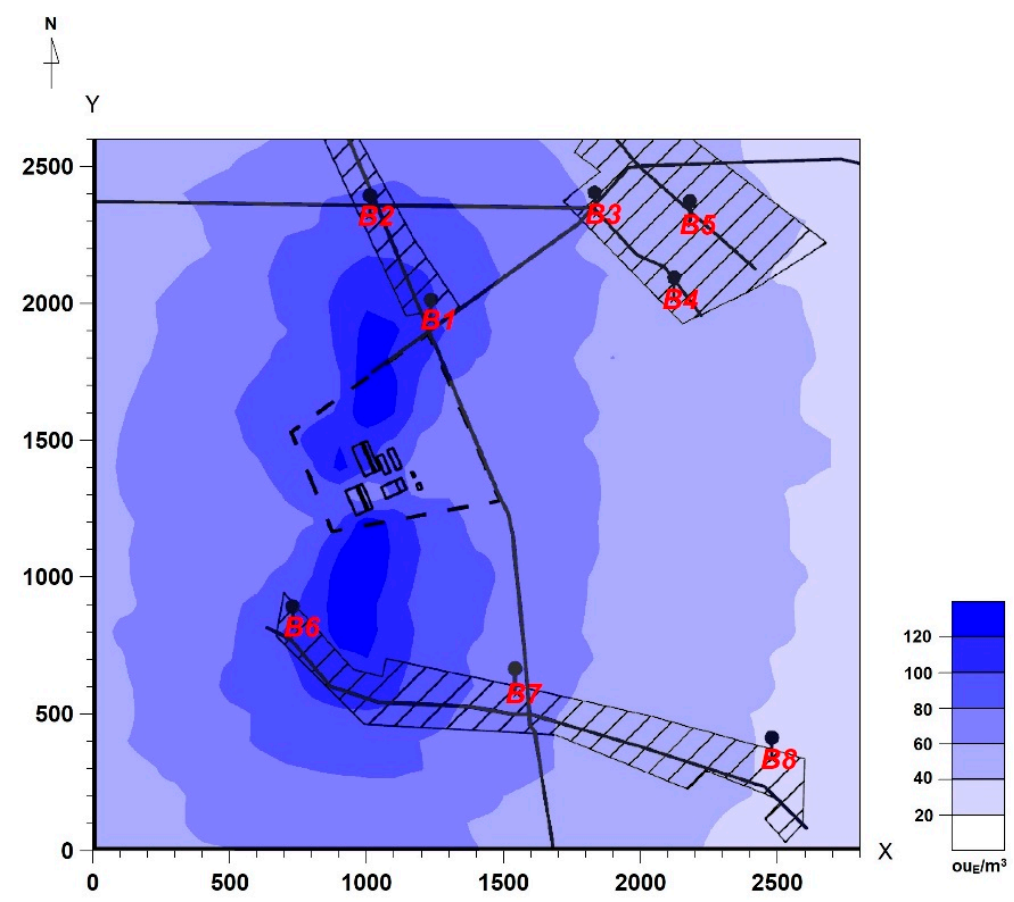

Figure 6. Maximum one-hour concentrations $\left(\mathrm{ou}_{\mathrm{E}} / \mathrm{m}^{3}\right)$ obtained for scenario 3. 


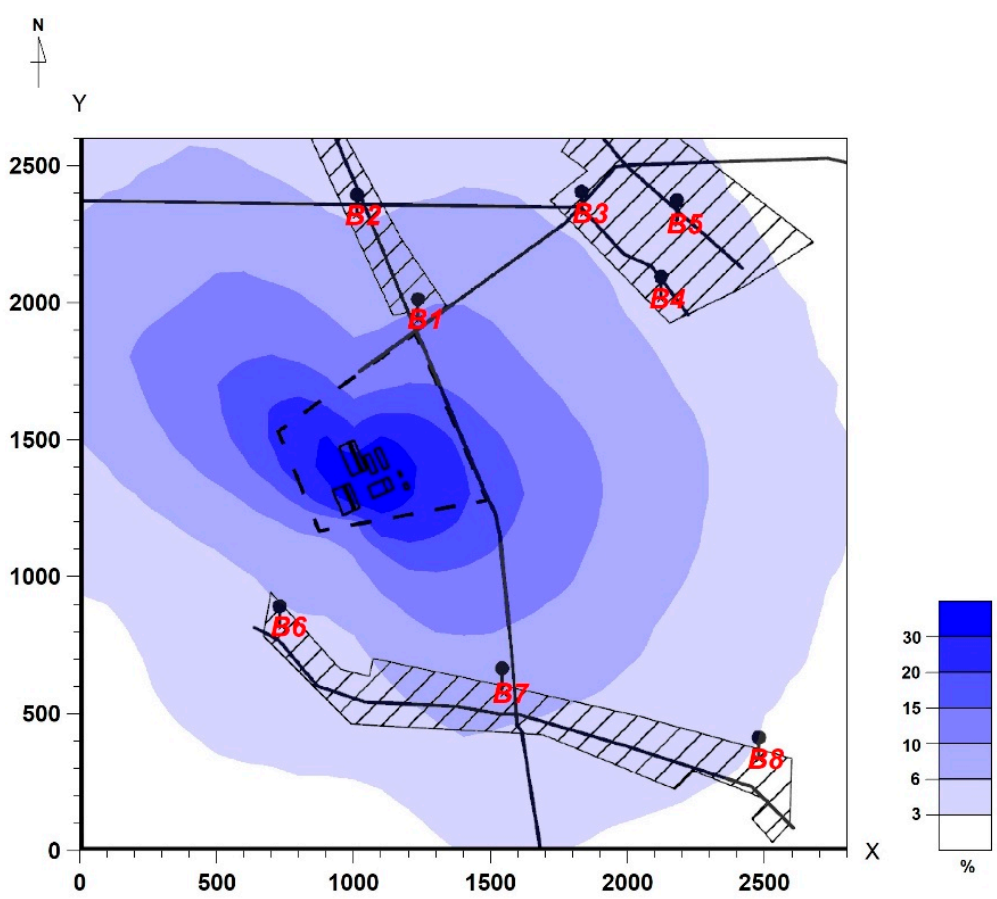

Figure 7. Frequency of exceedances $1 \mathrm{ou}_{\mathrm{E}} / \mathrm{m}^{3}$ for scenario 3 (permissible frequency of exceedances of $3 \%$ per year).

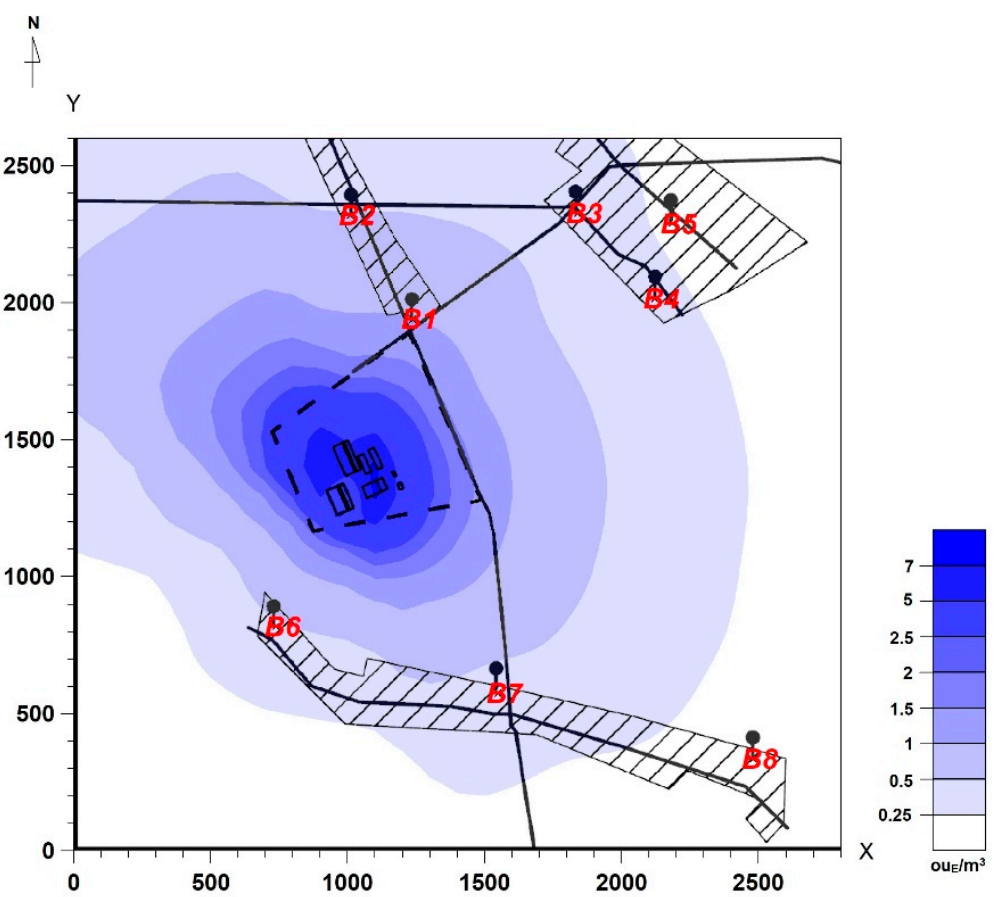

Figure 8. Average annual concentrations $\left(\mathrm{ou}_{\mathrm{E}} / \mathrm{m}^{3}\right)$ for scenario 3. 


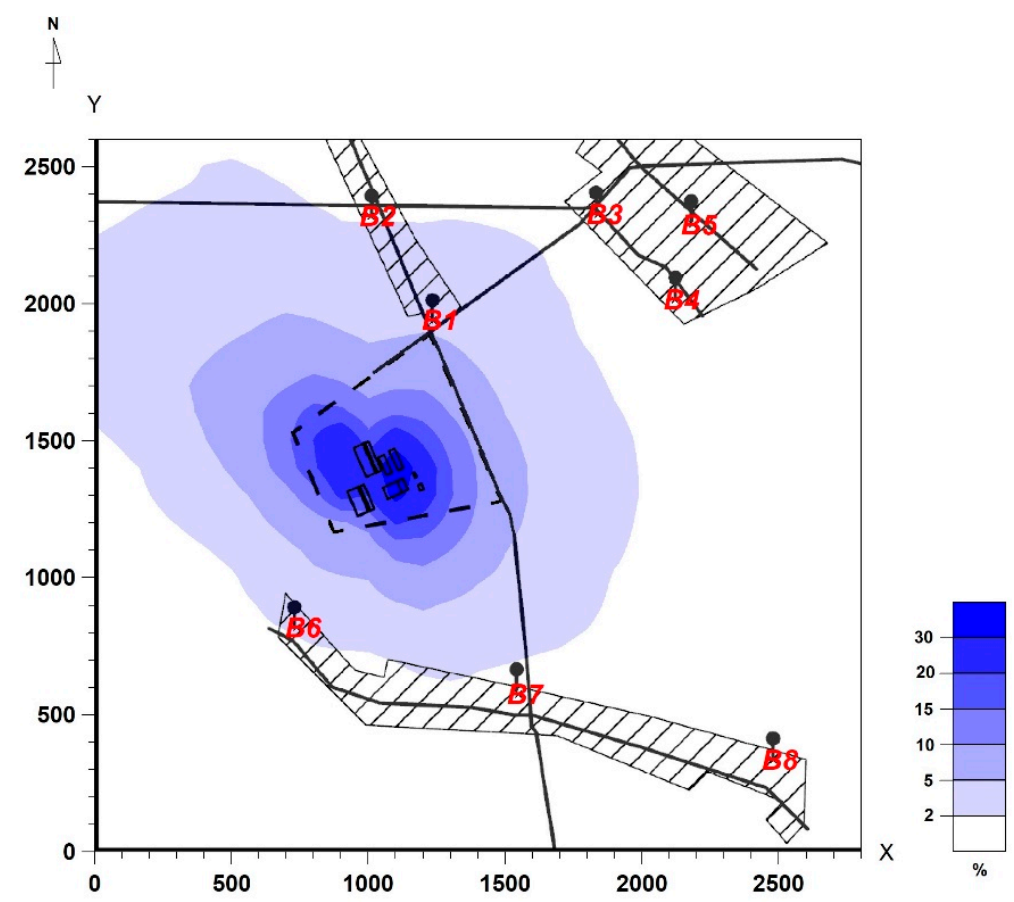

Figure 9. Frequency of exceedances $5 \mathrm{ou}_{\mathrm{E}} / \mathrm{m}^{3}$ for scenario 4 (permissible frequency of exceedances equal to $2 \%$ per year).

The maximum value of one-hour concentrations obtained for scenario 3 based on the Polish draft law [20] was $143 \mathrm{ou}_{\mathrm{E}} / \mathrm{m}^{3}(\mathrm{X}=1000, \mathrm{Y}=1100)$, it was read outside the plant boundaries, approx. $80 \mathrm{~m}$ from the southern border of the facility. The maximum frequency of exceedances obtained for scenario 3 was $45.06 \%(X=1100, Y=1400)$. The maximum average annual concentration recorded at this point $(X=1100, Y=1300)$ and was $7.5 \mathrm{ou}_{\mathrm{E}} / \mathrm{m}^{3}$. The maximum annual average concentrations and the maximum exceedance frequency were read at the premises. Figure 9 presents the frequency distribution of exceedances obtained for scenario 4 . The maximum value was obtained, as in the case of scenario 1 at the receptor point, $X=1100, Y=1400$ and amounted to $38.69 \%$.

Table 5 shows the modelling results obtained in the additional grid representing the nearest housing development for scenarios 3 and 4 . The results obtained for the additional grid, similar to the previous scenarios, i.e. scenario 1 and 2, show that the most unfavourable location in terms of the potential range of the odour impact of the tested object are buildings located in points B1 and B6. In the case of maximum concentrations, the value for point $\mathrm{B} 1$ is $106 \mathrm{ou}_{\mathrm{E}} / \mathrm{m}^{3}$, and for point $\mathrm{B} 6$, it is $103 \mathrm{ou}_{\mathrm{E}} / \mathrm{m}^{3}$ (these values are the same for scenarios 3 and 4 ). In the case of annual average concentrations at point $\mathrm{B} 1$, the value was $1.0 \mathrm{ou}_{\mathrm{E}} / \mathrm{m}^{3}$, at point $\mathrm{B} 2$ it was $0.5 \mathrm{ou}_{\mathrm{E}} / \mathrm{m}^{3}$. The value equal 0.5 was also read at point B2. The values of the maximum concentrations on the obtained distributions for scenarios 3 and 4 (Figure 6) are significantly lower than for scenarios 1 and 2 (Figure 2). The situation is similar in the case of annual average concentrations. The annual mean concentrations are significantly lower in scenarios 3 and 4 (Figure 8) than in scenarios 1 and 2 (Figure 4).

The last analysed criterion is the frequency of exceedances. In the case of scenario 3 , the highest value of the frequency of exceedances was found in point B1, and it amounts to $10.35 \%$. It exceeds the permissible frequency of exceedances equal to $3 \%$ per year for $1 \mathrm{ou}_{\mathrm{E}} / \mathrm{m}^{3}$. The permissible value of the frequency of exceedances is also exceeded in points B2-B7. There was no exceedance in point B8-value was equal $2.84 \%$. In the case of scenario 1 (Figure 3, Table 4), in all analysed points in the area of residential buildings, the value of the exceedance frequency is much higher than the permissible level of exceedance frequency of $3 \%$ per year for $1 \mathrm{ou}_{E} / \mathrm{m}^{3}$. When analysing the value of the frequency of exceedances for scenario 4 (permissible frequency of exceedances equal to $2 \%$ per annum for $5 \mathrm{ou}_{\mathrm{E}} / \mathrm{m}^{3}$ ), a significant improvement can be observed in comparison to scenario 3. The highest value of the 
exceedance frequency was found in item B1, and it amounts to $4.25 \%$. The permissible frequency of exceedances is also too high in the case of point B6-the value is $2.35 \%$. In the case of the remaining points (B2-B5 and B7, B8), the permissible frequency of exceedances of $2 \%$ per annum for $5 \mathrm{ou}_{\mathrm{E}} / \mathrm{m}^{3}$ was not exceeded. The obtained modelling results for the exceedance frequency parameter indicate that the application of various guidelines (Table 2) for the given scenarios may have an impact on the perception of the scope of the olfactory impact of the tested object. Comparing scenarios 1 and 2, as well as scenarios 3 and 4 , a direct difference can be seen in the obtained values of the frequency of exceedances. Even though in scenario 1 and 2 the exceedances of the permissible frequency of exceedances were recorded in each of the analysed points representing residential buildings, there is a difference between these scenarios. Scenario 2 has lower values than scenario 1 (Table 3). The difference between the scenarios is particularly visible in the case of scenarios 3 and 4: using the Dutch guidelines (Table 2) in scenario 4, a smaller number of points was recorded in residential buildings where the permissible frequency of exceedances was exceeded (the permissible value was exceeded in two of eight points); in scenario 3 based on the Polish bill (Table 2), the permissible value was exceeded in seven out of eight analysed points.

Table 5. Modelling results for scenarios 3 and 4 for an additional grid representing residential buildings.

\begin{tabular}{|c|c|c|c|c|c|c|}
\hline \multirow[b]{2}{*}{ Point Symbol } & \multicolumn{3}{|c|}{ Scenario 3} & \multicolumn{3}{|c|}{ Scenario 4} \\
\hline & $\begin{array}{c}\text { Maximum } \\
\text { One-Hour } \\
\text { Concentrations } \\
\left(\mathrm{ou}_{\mathrm{E}} / \mathrm{m}^{3}\right)\end{array}$ & $\begin{array}{l}\text { Average Annual } \\
\text { Concentrations } \\
\left(o u_{E} / m^{3}\right)\end{array}$ & $\begin{array}{c}\text { Frequency of } \\
\text { Exceedances } \\
(\%)\end{array}$ & $\begin{array}{c}\text { Maximum } \\
\text { One-Hour } \\
\text { Concentrations } \\
\left(\mathrm{ou}_{\mathrm{E}} / \mathrm{m}^{3}\right)\end{array}$ & $\begin{array}{l}\text { Average Annual } \\
\text { Concentrations } \\
\left(\mathrm{ou}_{\mathrm{E}} / \mathrm{m}^{3}\right)\end{array}$ & $\begin{array}{c}\text { Frequency of } \\
\text { Exceedances } \\
(\%)\end{array}$ \\
\hline B1 & 106 & 1.0 & 10.35 & 106 & 1.0 & 4.25 \\
\hline B2 & 87 & 0.5 & 5.72 & 87 & 0.5 & 1.98 \\
\hline B3 & 58 & 0.3 & 5.30 & 58 & 0.3 & 1.42 \\
\hline B4 & 50 & 0.3 & 5.17 & 50 & 0.3 & 1.13 \\
\hline B5 & 47 & 0.2 & 3.84 & 47 & 0.2 & 0.88 \\
\hline B6 & 103 & 0.5 & 5.60 & 103 & 0.5 & 2.35 \\
\hline B7 & 69 & 0.4 & 7.05 & 69 & 0.4 & 1.56 \\
\hline B8 & 38 & 0.2 & 2.84 & 38 & 0.2 & 0.73 \\
\hline
\end{tabular}

\section{Conclusions}

The aim of the research was to determine the odour impact range with the use of the Polish reference model by making odour concentration measurements and determining odour emission from sources selected in the area of a chosen agricultural processing facility. In the odour impact analysis, four calculation scenarios were assumed using the modelling of the dispersion of odour pollutants to assess the odour impact of the tested object. The assumed scenarios differed in the adopted comparative levels of the permissible concentration of odours in the air, the permissible frequency of exceeding the comparative level, and the type of emitters included in the modelling. Scenarios 1 and 2 take into account all sources identified in the area of the studied facility, both point and surface sources. In contrast, scenarios 3 and 4 only include point sources (characteristics of the sources are presented in Tables 1 and 3). The performed calculations, on the basis of the obtained concentration distributions, showed that the tested object can have a significant odour effect, and considering the fact that in the calculations the averaging time was one hour (presented in the regulatory requirements) of the true odour impact, since short term (sub-hourly) concentrations can be much higher [33], real exceedances can be much higher. In the case of scenarios 1 and 2, which take into account all sources, the results indicate that at each point representing residential buildings, the permissible level of exceedance frequency was exceeded, regardless of the guidelines applied. The values of exceedances of the permissible frequency of exceedances are lower in scenario 2 . This is due to the application of other guidelines. In the case of scenarios 3 and 4 , only point sources were used, which are characterised by a significantly lower odour effect. In scenario 3, the permissible value of the frequency of exceedances was high in one out of eight points representing the buildings of the inhabitants. In the case of scenario 4 , the permissible value of the frequency of exceedances was not exceeded in six out of eight points representing residential buildings. 
The conducted research also allowed for the assessment of the share of individual sources in the total odour emission. The conducted analyses show that unorganised surface sources have the largest share in the emissions from the tested plant, as they are responsible for $93.91 \%$ of the emission of unpleasant odours. Among them, the most troublesome in terms of odour emission are storage boxes without a roof (eight units), which account for $27.71 \%$ of the total emission, and leachate tanks, which account for $19.15 \%$ of the total emission of unpleasant odours. In the case of organised point sources, their percentage share in the total emission in the area of the examined facility was much lower and amounted to $6.09 \%$. The results indicate that the emitters associated with the pasteurisation process were the most odourogenic. Their location in hall A contributed to $1.48 \%$, and in hall B to $3.32 \%$ of the total odour emissions from the tested facility.

Determining the significant share of surface sources in the total odour emissions indicated the need to take measures to reduce emissions in the area of the tested facility, in the first place, from this type of sources. According to the 'Codex of Counteracting Odour Nuisance' [34], which is a document of recommendation in Poland, surface sources should be sealed as far as possible. Encapsulation changes the nature of the source and allows for capturing and collecting gases. For the gases in question containing large amounts of ammonia, the recommended method of deodorisation is absorption (the use of a spray scrubber). Additionally, fogging and the use of odour masking methods are recommended as emergency methods or to reduce emissions from fugitive sources (e.g. chicken coop). The plant could also take additional measures at the operational stage, such as shortening the time of storing the chicken coop, optimisation of transhipment processes or optimisation of the composting process. Such activities should improve air quality and minimize the discomfort of residents living in the zones where the permissible odour concentration values may be exceeded.

Author Contributions: Conceptualization, I.S.; methodology, I.S., M.P., U.M., and A.G..; software, M.P. and Y.B.; validation, I.S. and M.P.; formal analysis, I.S.; investigation, I.S. and M.P.; writing — original draft preparation, I.S., M.P., U.M., A.G., A.W., and Y.B.; writing-review and editing, I.S., M.P., U.M., A.G., A.W., and Y.B.; visualisation, M.P.; supervision, I.S. All authors have read and agreed to the published version of the manuscript.

Funding: This work was co-financed within the "Excellent Science" program of the Polish Ministry of Science and Higher Education.

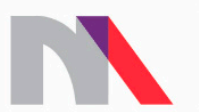

Ministry of Science and Higher Education

Republic of Poland

Conflicts of Interest: The authors declare no conflict of interest.

\section{References}

1. Rappert, S.; Müller, R. Odor compounds in waste gas emissions from agricultural operations and food industries. Waste Manag. 2005, 25, 887-907. [CrossRef]

2. Sówka, I.; Miller, U.; Karski, L. Analysis of legal and technical solutions in terms of odours in Poland. Environ. Prot. Eng. 2019, 45, 127-138. [CrossRef]

3. The Draft of Polish Law of 28 March 2019: Act on the Minimum Distance for a Planned Project in the Agricultural Sector, the Functioning of Which May Be Associated with the Risk of Odor Nuisance. Available online: https://legislacja.rcl.gov.pl/docs//2/12321413/12579307/12579308/dokument387164.pdf (accessed on 26 March 2020).

4. Noble, R.; Hobbs, P.J.; Mead, A.; Dobrovin-Pennington, A. Influence of straw types and nitrogen sources on mushroom composting emissions and compost productivity. J. Ind. Microbiol. Biotechnol. 2002, 29, 99-110. [CrossRef] [PubMed]

5. Noble, R.; Hobbs, P.J.; Dobrovin-Pennington, A.; Misselbrook, T.H.; Mead, A. Olfactory response to mushroom composting emissions as a function of chemical concentration. J. Env. Qual. 2001, 30, 760-767. [CrossRef] [PubMed] 
6. Pecchia, J.A.; Beyer, D.M.; Wuest, P.J. The Effects of Poultry ManureBased Formulations on odor generation during phase i mushroom composting. Compost. Sci. Util. 2020, 10, 188-196. [CrossRef]

7. Capelli, L.; Sironi, S.; Del Rosso, R.; Huillot, J.M. Measuring odours in the environment vs. dispersion modelling: A review. Atmos. Environ. 2013, 79, 731-743. [CrossRef]

8. Wroniszewska, A.; Zwoździak, J. Odor annoyance assessment by using logistic regression on an example of the municipal sector. Sustainability 2020, 12, 6102. [CrossRef]

9. Moshammer, H.; Oettl, D.; Mandl, M.; Kropsch, M.; Weitensfelder, L. Comparing annoyance potency assessments for odors from different livestock animals. Atmosphere 2019, 10, 659. [CrossRef]

10. Preamble to the Constitution of $\mathrm{WHO}$ as adopted by the International Health Conference. New York, NY, USA, 19 June-22 July 1946. Available online: https://www.who.int/governance/eb/who_ constitution_en.pdf (accessed on 26 March 2020).

11. Schiffman, S.S.; Williams, C.M. Science of odor as a potential health issue. J. Environ. Qual. 2005, 34, 129-138.

12. Shusterman, D.; Lipscomb, J.; Neutra, R.; Satin, K. Symptom prevalence and odor-worry interaction near hazardous waste sites. Environ. Health Perspect. 1991, 94, 25-30.

13. Beach, J.R.; Raven, J.; Ingram, C.; Bailey, M.; Johns, D.; Walters, E.H.; Abramson, M. The effects on asthmatics of exposure to a conventional water-based and a volatile organic compound-free paint. Eur. Respir. J. 1997, 10, 563-566. [PubMed]

14. Pawnuk, M.; Sówka, I. Application of mathematical modelling in evaluation of odour nuisance from selected waste management plant. E3S Web Conf. 2019, 100, 1-8, ID: 00063. [CrossRef]

15. Bax, C.; Sironi, S.; Capelli, L. How can odors be measured? An overview of methods and their applications. Atmosphere. 2020, 11, 92. [CrossRef]

16. Park, S. Odor characteristics and concentration of malodorous chemical compounds emitted from a combined sewer system in Korea. Atmosphere. 2020, 11, 667. [CrossRef]

17. Invernizzi, M.; Brancher, M.; Sironi, S.; Capelli, L.; Piringer, M. Odour impact assessment by considering short-term ambient concentrations: A multi-model and two-site comparison. Environ. Int. 2020, 144, 105990. [CrossRef] [PubMed]

18. Wu, C.; Brancher, M.; Yang, F.; Liu, J.; Qu, C.; Schauberger, G.; Piringer, M. A comparative analysis of methods for determining odour-related separation distances around a dairy farm in Beijing, China. Atmosphere. 2019, 10, 231. [CrossRef]

19. Sówka, I.; Bezyk, Y.; Grzelka, A.; Miller, U.; Pachurka, Ł. Seasonal odor impact range of selected wastewater treatment plants-modeling studies using Polish reference model. Water Sci. Technol. 2018, 2017, 422-429.

20. Polish Ministry of Environment. Polish Ministry of Environment Draft Act: Law on the Prevention of Odor Nuisance; Polish Ministry of Environment: Warsaw, Poland, 2009.

21. Romanik, E.; Pawnuk, M.; Sówka, I. Assessment of odour impact range of selected waste management plant with the use of mathematical tools (Model Tools). J. Ecol. Eng. 2019, 20, 94-101. [CrossRef]

22. Romanik, E.; Bezyk, Y.; Pawnuk, M.; Miller, U.; Grzelka, A. Influence of the variability of the odour emission rate on its impact range: A case study of the selected industrial source. E3S Web Conf. 2019, 100, 1-8, ID: 00070. [CrossRef]

23. Piringer, M.; Schauberger, G. Dispersion modelling for odour exposure assessment. In Odor Impact Assessment Handbook; Belgiorno, V., Naddeo, V., Zarra, T., Eds.; Wiley: New York, NY, USA, 2013; pp. 125-174.

24. St. Croix Sensory, Inc., Nasal Ranger Field Olfactometer Operation Manual. Available online: https: //www.fivesenses.com/equipment/nasalranger/nasalranger/ (accessed on 26 March 2020).

25. Polish Committee for Standardization. Polish Standard PN-EN 13725:2007: Air Quality —Determination of Odour Concentration by Dynamic Olfactometry; Polish Committee for Standardization: Warsaw, Poland, 2007.

26. VDI (Verein Deutscher Ingenieure). VDI 3880: Olfactometry. Static Sampling, Verein Deutscher Ingenieure; VDI (Verein Deutscher Ingenieure): Düsseldorf, Germany, 2011.

27. Sówka, I.; Miller, U.; Sobczyński, P. Dynamic olfactometry and modeling as methods for the assessment of odour impact of public utility objects. Environ. Prot. Eng. 2016, 42, 143-152.

28. Lucernoni, F. The evaluation of the odour emission rate for passive area sources: A new approach. Chem. Eng. Trans. 2015, 43, 2149-2154.

29. Polish Minister of the Environment. Regulation of the Polish Minister of the Environment of 26 January 2010 on Reference Value for Some Substances in the Air; Polish Minister of the Environment: Warsaw, Poland, 2010; No. 16 item 87. (In Polish) 
30. PROEKO Ryszard Samoć, Operat Fb Software. Available online: https://www.proeko.kalisz.pl/Operat_FB. html (accessed on 26 March 2020).

31. Prata, A.A.; Lucernoni, F.; Santos, J.M.; Capelli, L.; Sironi, S.; Le-Minh, N.; Stuetz, R.M. Mass transfer inside a flux hood for the sampling of gaseous emissions from liquid surfaces-Experimental assessment and emission rate rescaling. Atmos. Environ. 2018, 179, 227-238. [CrossRef]

32. Hudson, N.; Ayoko, G.A. Odour sampling. 2. Comparison of physical and aerodynamic characteristics of sampling devices: A review. Bioresour. Technol. 2008, 99, 3993-4007. [CrossRef]

33. Brancher, M.; Hieden, A.; Baumann-Stanzer, K.; Schauberger, G.; Piringer, M. Performance evaluation of approaches to predict sub-hourly peak odour concentrations. Atmos. Environ. X 2020, 7, 100076. [CrossRef]

34. Codex on Preventing of Odour Nuisance. Available online: https://www.gov.pl/web/klimat/uciazliwosczapachowa. (accessed on 26 March 2020). (In Polish)

(C) 2020 by the authors. Licensee MDPI, Basel, Switzerland. This article is an open access article distributed under the terms and conditions of the Creative Commons Attribution (CC BY) license (http://creativecommons.org/licenses/by/4.0/). 